\title{
Design of Eco Bags on the Basis of LOHAS and Consumption Behavior
}

\author{
Qing Li
}

\begin{abstract}
Nowadays, an increasing number of people is aware of the detrimental results of environment pollution in global scale. Some of the population has changed their lifestyles and has switched to eco bags to tone down the impact on human inhabitation on earth. Eco bags, which are renewable, are good for environment because they are both recyclable and degradable. The purpose of this paper is for businesses or government agencies to better locate and understand a particular market segment and potential demands of environment-friendly bags. By this research, the author hopes to not only increase businesses' sales but also meet demands of consumers living in Lifestyles of Health and Sustainability. (LOHAS). By quantitative research, this study analyzes relationships between demands of eco bags with various sizes, designs, shapes as well as applications, and purchasers of different education background, career, and age. Furthermore, it also examines the difference between LOHAS purchasers' behavior and visual sensation, style, size, and shape. Last but not the least, this paper establishes a model of the influence of LOHAS' concept and way of living on eco bags consumption by official data of Macao population. Since LOHAS' advocators react differently to visual effect, style, size and graphic design of eco bags, bags manufacturers should take these dissimilar requests into consideration when they fashion their products. In this way, it is more likely for manufacturers to penetrate into the market segment and access to more potential LOHAS consumers by producing desired items. Meanwhile, organizations or government agencies with interest in this particular market segment can be well informed for policies making or related administrative purposes based on the models presented in this paper.
\end{abstract}

Index Terms-Consumption behavior, design, eco bags, LOHAS.

\section{INTRODUCTION}

Currently, there are a lot of environmental disasters including species extinction, temblor, flood, and tsunami, which poses great threat to the survival of human being.

In 1998, Paul H.Ray, as a sociologist, and Sherry Ruth Anderson, as a psychologist, point out the definition of LOHAS in a book called The Cultural Creative: How 50 Million People are Changing the World. LOHAS is lifestyles of health and sustainability [1]. Health means a lifestyle of health and environment protection, personal growth, and health care. Sustainability means a spirit of ecological sustainability [2].

A multitude of plastic bags not only waste resources, but also destroy environment. They introduce negative impacts

Manuscript received December 10, 2012; revised February 10, 2013.

Qing. Li is with faculty of management, City University of Macau, Macau, China. Author is studying business administration for doctor degree (e-mail: mydegrass@163.com). to human health because most of raw materials of plastic bags come from petroleum which is a non-renewable resource. Due to the fact that it takes a thousand years for plastic bags to rot in deep underground, soil is seriously polluted and there are poisonous gas, and smog while firing.

John Muir, as a leader of environment protection movement in the USA, claimed the concept of reduce, reuse, and recycle [3].Then more and more people's environment awareness is aroused. As a result, some enterprises have produced new environmental products including eco bags. LOHAS people hold views which protect earth and avoid the waste of natural resources for the benefit of human health and survival of human being. The value is embedded in their life. Therefore they buy and use eco bags, and recommend eco bags to their members of family, relatives, colleagues, and friends. Eco bags have become a taste of green consumption.

\section{Situation of EnVironment Protection}

LOHAS people concern healthy life, sustainable eco-protection, and physical along with mental pleasure. Lifestyle of LOHAS not only creates value of some economic output in marketing, but also benefits the society of low carbon [4].

Organizations in society hold various environment protection activities and knowledge of environment protection lectured in school, and government promotes this concept as well. Moreover, citizen devotes themselves to design environment friendly product. It proves that the problems of environment have aroused citizens' concentration in Macao. As a result of responding to the voices of consumers in Macao, some ecological minded local enterprises have put the idea of environment protection in the designs of eco bags. An opinion of LOHAS still is a beginning stage because LOHAS is led into citizen's life gradually.

\section{DESCRIPTIVE STATISTICS}

On the basis of references, the research makes questionnaires and the total questionnaires are issued 260 in Macao, but actual recycling questionnaire only is 225 . The ratio of callback of valid is $86.54 \%$. The valid date in this questionnaire is processed by SPSS.

\section{A. Design of Descriptive Statistics}

Patterns consist of natural landscape, letter, cartoon, animal, plant, sport, and figure. In all the patterns, natural landscape accounts for $18.67 \%$ with the biggest percentage. Plant's percentage and sport's percentage are the smaller 
percentages of all the patterns and their percentage is $18.22 \%$ and $14.67 \%$ of all patterns respectively. Letter, animal and figure account for about $12 \%$ of all patterns separately. Whereas cartoon makes up less than $12 \%$ of all patterns and this percentage is the smallest percentage.

Shapes consist of rectangle, square, oval, rhombus, and trapezoid. In all shapes, rectangle and oval share bigger percentage than others' and their percentages are $25.78 \%$ respectively. Rhombus' percentage and square' percentage are the smaller percentage of all shapes and their percentages are $19.22 \%$ and $17.55 \%$ of all shapes respectively. However, trapezoid makes up merely $11.67 \%$ of all shapes with the smallest percentage.

Colors are composed of bright and light color. Light color makes up $55.11 \%$ of all colors, and this percentage is $44.89 \%$ larger than the percentage of bright color.

Sizes are composed of big, middle, and small sizes. In all sizes, the middle sizes account for $42.22 \%$ with the largest percentage. The small size' percentage is the second largest percentage with $31.56 \%$ of all sizes. The big size accounts for $26.22 \%$ of all sizes with the smallest percentage.

\section{B. Demographic Variables}

The careers consist of teachers, employees, doctors, students, managers, and others. The percentages of people who work or study in education reach $50 \%$ because in all careers, students and teachers account for $31.11 \%$ and $20 \%$, which is followed by employees and doctors with $18.67 \%$ and $11.11 \%$ respectively. Smaller percentages are managers' and others' with less than $10 \%$ in all careers respectively.

The age groups are composed by categories of those under 25 and above 56, as well as groups of those from 26 to 35,36 to 45 , and 46 to 55 . In all ages, people under 25 make up $27.56 \%$, and the people in the range of $46-55,26-35$ as well as $36-45$ years old account for $23.56 \%, 20.45 \%$ as well as $17.78 \%$ respectively. People aged above 56 account for $10.65 \%$ of all ages.

The genders consist of both female and male. In the genders, female makes up $60.44 \%$ and this percentage is $39.56 \%$ larger than males' percentage.

The degrees are composed of high school, bachelor, master, and doctor. In all degrees, there are $40 \%$ of people with bachelor degree, $28.44 \%$ of people with master degree, and $10.67 \%$ of people with doctor degree. The percentages of higher education including bachelor, master, and doctor are about $80 \%$. Compared to holders with higher degree, people who have lower degree only account for approximately $20 \%$ of all degrees.

In all incomes, people who earn salary from 10001 to 15000 make up 26.67\%. People who acquire salary from 20001 to 25000 make up $23.11 \%$ of all incomes. People who receive salary from 15001 to 20000 make up $20 \%$ of all incomes. People who get salary above 25001 and under 10000 make up $16.89 \%$ and $13.33 \%$ of incomes respectively.

According to consumers' preference, consumers who choose eco bags on a top priority account for $42.67 \%$ of all consumers in this investigation. Meanwhile this percentage is smaller than the percentage of people who seldom choose eco bags a top priority with $57.33 \%$ of all consumers.

The applications of eco bags are for grocery shopping, daily usage, books, documents, and other common utilizations of carry-on bags. In all functions, eco bags used for food and daily necessity account for $46 \%$, for book or document account for $36 \%$, and for other functions account for $18 \%$. Eco bags filled with basic commodity are used by people widely.

\section{TARget CONSUMERS AND DESIGN OF ECO BAGS}

In terms of principle of LOHAS and design of eco bags, questionnaire is made [2] and [5]. One of parts in this questionnaire is preferences of eco bags involving size, color, shape, and pattern, and personal basic information, such as education, vocation, age and so on.

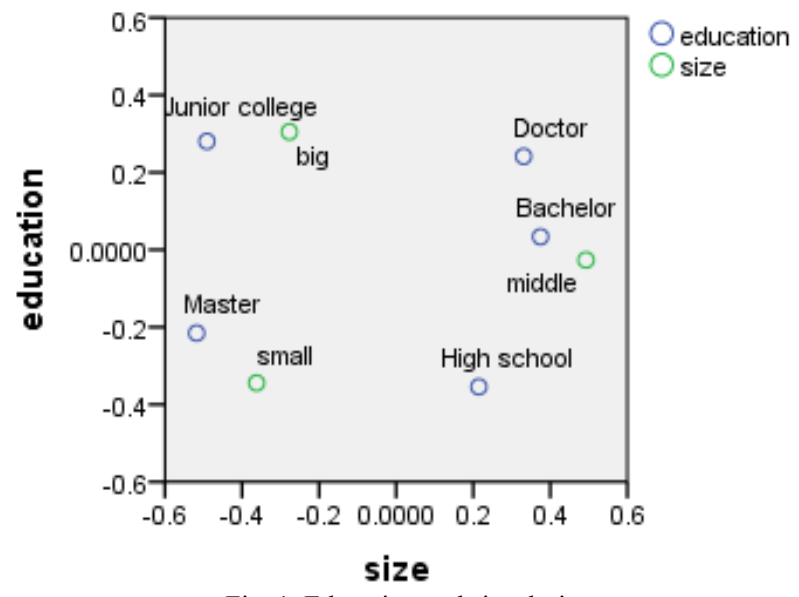

Fig. 1. Education and size design

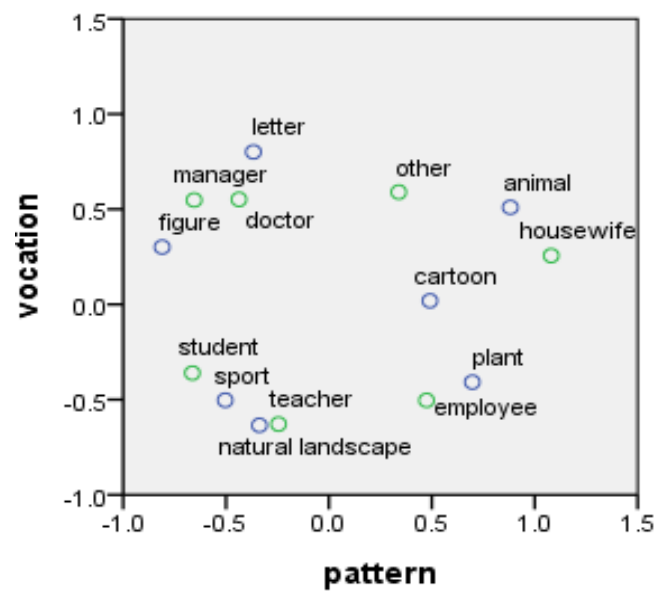

Fig. 2. Vocation and pattern design

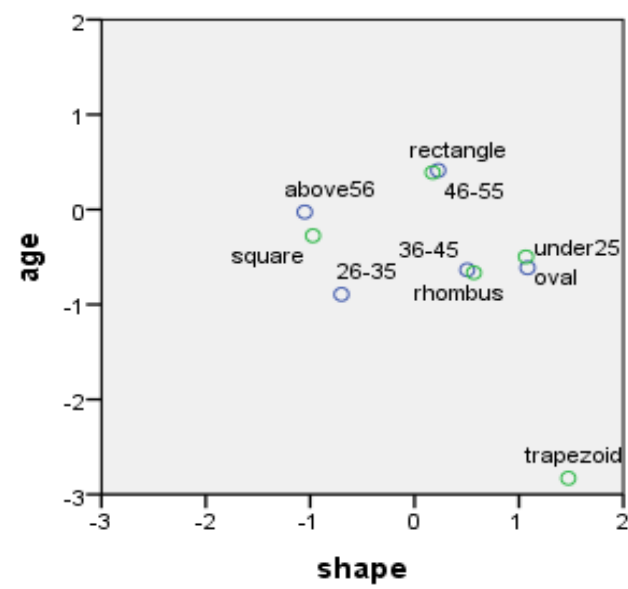

Fig. 3. Age and shape design
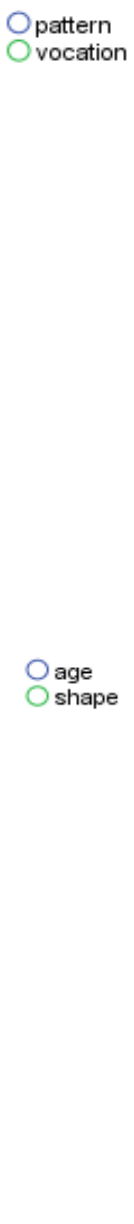
As is shown in the Fig. 1, Junior college is closed to big sizes, master is closed to small sizes, and bachelor is closed to middle sizes. It illustrates that there are close relationships between education and sizes. According to the corresponding relationship, target consumers for big sizes are mainly junior college degree holders. Target consumers for small sizes are mainly master degree holders. Target consumers for middle sizes are mainly bachelor degree holders.

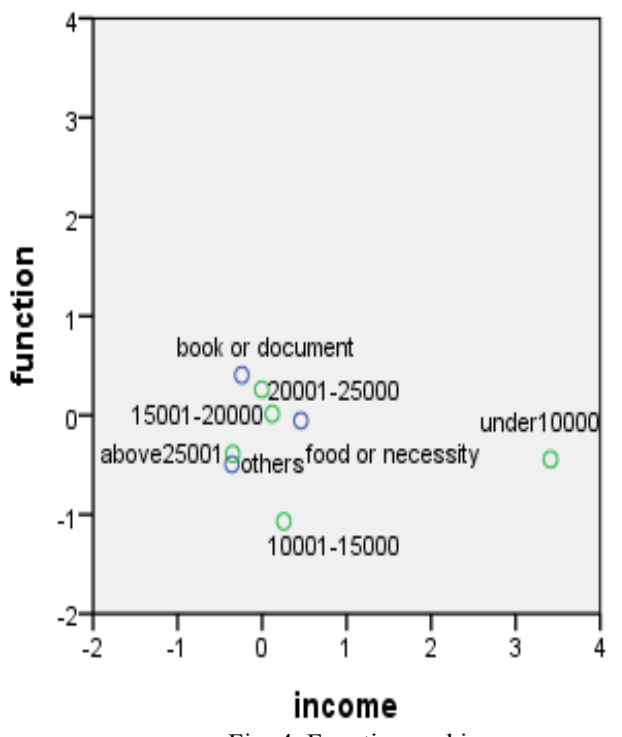

Fig. 4. Function and income

As is shown in the Fig. 2, teacher is closed to natural landscape design, student is closed to sport design, employee is closed to plant design, doctor is closed to letter design, manager is closed to figure design, and housewife is closed to animal design. It illustrates that there are close relationships between each category which indicates a consumption preference.

As is shown in the Fig. 3, people under 25 are closed to design of oval, people of 36-45 years old are closed to design of rhombus, people of 46-55 years old are closed to design of rectangle, and people above 56 are closed to design of square. The demonstrated relationships in each group are indicators of various consumption inclinations for different shapes.

As is shown in the fig.4, people who obtain income in the range of 20001-25000 are close to people who use eco-bags to carry books or documents. What is more, people who are in the income bracket of 15001-20000 are close to those who take eco-bags to filled food or daily necessity. Meanwhile, people who obtain income above 25001 take eco bags to contain others. These corresponding relationships indicate strong preferences in eco bags in these income groups.

\section{DifFERENCE ANALYSIS}

\section{A. LOHAS and Vision Designs}

As can be seen in the Table I, one variable is that I am satisfied with current society and hold optimistic attitude for future and other variable is vision designs. Their observed significance level is less than 0.05 . The results show that there are differences both of them. In addition, one variable is that I usually use environment-friendly products and other variable is vision designs. Their observed significance level is less than 0.05 . The results show that there are differences both of them.

TABLE I: LOHAS AND DESIGN OF ECO BAGS

\begin{tabular}{|c|c|c|c|c|c|}
\hline & \multirow{2}{*}{$\mathrm{LOHAS}_{\text {LOHA }}^{\text {Design }}$} & \multicolumn{2}{|l|}{ vision } & \multicolumn{2}{|c|}{ pattern } \\
\hline & & F & Sig. & $\mathrm{F}$ & Sig. \\
\hline \multirow{8}{*}{$\begin{array}{l}\mathrm{L} \\
\mathrm{O} \\
\mathrm{H} \\
\mathrm{A} \\
\mathrm{S}\end{array}$} & $\begin{array}{l}\text { I am keen on natural } \\
\text { environment along } \\
\text { with worry about } \\
\text { pollution of natural } \\
\text { environment. }\end{array}$ & 0.309 & 0.579 & 0.721 & 0.633 \\
\hline & $\begin{array}{l}\text { am satisfied with } \\
\text { current society and } \\
\text { hold optimistic attitude } \\
\text { for future. }\end{array}$ & 9.682 & $\begin{array}{l}0.002 \\
*\end{array}$ & 1.610 & 0.145 \\
\hline & $\begin{array}{l}\text { I usually use } \\
\text { environment-friendly } \\
\text { products. }\end{array}$ & 2.579 & $\begin{array}{l}0.010 \\
*\end{array}$ & 0.487 & 0.818 \\
\hline & $\begin{array}{l}\text { I actively participate in } \\
\text { activities } \\
\text { environment as a } \\
\text { volunteer. }\end{array}$ & 1.300 & 0.255 & 0.263 & 0.953 \\
\hline & $\begin{array}{l}\text { I am concerned about } \\
\text { my health and family } \\
\text { health. }\end{array}$ & 0.650 & 0.421 & 0.733 & 0.624 \\
\hline & $\begin{array}{l}\text { I like experience of life } \\
\text { and continuing } \\
\text { learning. }\end{array}$ & 1.674 & 0.197 & 0.538 & 0.779 \\
\hline & $\begin{array}{l}\text { I often take exercises } \\
\text { and enjoy leisure } \\
\text { activities. }\end{array}$ & 0.365 & 0.546 & 1.844 & $\begin{array}{l}0.032 \\
*\end{array}$ \\
\hline & $\begin{array}{l}\text { I shape good moral and } \\
\text { take care of other } \\
\text { people. }\end{array}$ & 1.757 & 0.186 & 3.543 & $\begin{array}{c}0.002 \\
*\end{array}$ \\
\hline
\end{tabular}

TABLE II: LOHAS AND DESIGN OF ECO BAGS

\begin{tabular}{|c|c|c|c|c|c|}
\hline & \multirow{2}{*}{$\mathrm{LOHAS}_{\text {LOSign }}^{\text {Design }}$} & \multicolumn{2}{|l|}{ vision } & \multicolumn{2}{|c|}{ pattern } \\
\hline & & $\mathrm{F}$ & Sig. & F & Sig. \\
\hline \multirow{8}{*}{$\begin{array}{l}\text { L } \\
\text { O } \\
\text { H } \\
\text { A } \\
\text { S }\end{array}$} & $\begin{array}{l}\text { I am keen on natural } \\
\text { environment along } \\
\text { with worry about } \\
\text { pollution of natural } \\
\text { environment. }\end{array}$ & 5.463 & $\begin{array}{l}0.005 \\
*\end{array}$ & 2.190 & 0.071 \\
\hline & $\begin{array}{l}\text { am satisfied with } \\
\text { current society and } \\
\text { hold optimistic attitude } \\
\text { for future. }\end{array}$ & 2.972 & $\begin{array}{l}0.049 \\
*\end{array}$ & 4.757 & $\begin{array}{l}0.041 \\
*\end{array}$ \\
\hline & $\begin{array}{l}\text { I usually use } \\
\text { environment-friendly } \\
\text { products. }\end{array}$ & 3.011 & $\begin{array}{l}0.046 \\
*\end{array}$ & 3.046 & $\begin{array}{l}0.043 \\
*\end{array}$ \\
\hline & $\begin{array}{l}\text { I actively participate in } \\
\text { activities } \\
\text { environment as a } \\
\text { volunteer. }\end{array}$ & 5.239 & $\begin{array}{l}0.006 \\
*\end{array}$ & 6.668 & $\begin{array}{l}0.000 \\
*\end{array}$ \\
\hline & $\begin{array}{l}\text { I am concerned about } \\
\text { my health and family } \\
\text { health. }\end{array}$ & 4.413 & $\begin{array}{l}0.013 \\
*\end{array}$ & 8.744 & $\begin{array}{l}0.000 \\
*\end{array}$ \\
\hline & $\begin{array}{l}\text { I like experience of life } \\
\text { and continuing } \\
\text { learning. }\end{array}$ & 5.009 & $\begin{array}{l}0.007 \\
*\end{array}$ & 9.458 & $\begin{array}{l}0.000 \\
*\end{array}$ \\
\hline & $\begin{array}{l}\text { I often take exercises } \\
\text { and enjoy leisure } \\
\text { activities. }\end{array}$ & 3.760 & $\begin{array}{l}0.025 \\
*\end{array}$ & 9.427 & $\begin{array}{l}0.000 \\
*\end{array}$ \\
\hline & $\begin{array}{l}\text { I shape good moral and } \\
\text { take care of other } \\
\text { people. }\end{array}$ & 0.852 & 0.428 & 8.313 & $\begin{array}{l}0.000 \\
*\end{array}$ \\
\hline
\end{tabular}

\section{B. LOHAS and Pattern Designs}

As can be seen in the Table I, one variable is that I often 
take exercises and enjoy leisure activities and other variable is pattern designs. Their observed significance level is less than 0.05 . The results show that there are differences both of them. In addition, one variable is that I shape good moral and take care of other people and other variable is pattern designs. Their observed significance level is less than 0.05 . The results show that there are differences both of them.

\section{LOHAS and Size Designs}

As can be seen in the Table II, except for the variable that I shape good moral and take care of other people, there are difference among other variables of LHOHS and size designs.

\section{LOHAS and Shape Designs}

As can be seen in the Table II, except for the variable that I am keen on natural environment along with worry about pollution of natural environment and shape designs, there are differences among other variables of LOHAS and shape designs.

\section{E. LOHAS and Consumption Behavior}

As can be seen in the Table III, all observed significance level is less than 0.05 . The result illustrates there are differences among all variables of LOHAS and those who choose eco bag on a top priority while consuming.

TABLE III: LOHAS AND CONSUMPTION BEHAVIOR

\begin{tabular}{|l|l|l|l|l|}
\hline \multicolumn{2}{|c|}{} & \multicolumn{3}{|l|}{ Consumption Behavior } \\
\cline { 2 - 4 } \multicolumn{2}{|c|}{} & Mean & F & Sig. \\
\hline $\begin{array}{l}\text { I am keen on natural environment } \\
\text { along with worry about pollution of } \\
\text { natural environment. }\end{array}$ & 3.31 & 3.112 & $\begin{array}{c}0.002 \\
*\end{array}$ \\
\hline $\begin{array}{l}\text { I am satisfied with current society and } \\
\text { hold optimistic attitude for future. }\end{array}$ & 3.39 & 2.691 & $\begin{array}{c}0.006 \\
*\end{array}$ \\
\hline $\begin{array}{l}\text { I usually use environment-friendly } \\
\text { products. }\end{array}$ & 3.28 & 3.027 & $\begin{array}{c}0.002 \\
*\end{array}$ \\
\hline $\begin{array}{l}\text { I actively participate in activities of } \\
\text { environment as a volunteer. }\end{array}$ & 3.75 & 6.822 & $\begin{array}{c}0.000 \\
*\end{array}$ \\
\hline $\begin{array}{l}\text { I am concerned about my health and } \\
\text { family health. }\end{array}$ & 3.91 & 8.161 & $\begin{array}{c}0.000 \\
*\end{array}$ \\
\hline $\begin{array}{l}\text { I like experience of life and continuing } \\
\text { learning. }\end{array}$ & 3.82 & 6.047 & $\begin{array}{c}0.000 \\
*\end{array}$ \\
\hline $\begin{array}{l}\text { I often take exercises and enjoy leisure } \\
\text { activities. }\end{array}$ & 3.94 & 45.154 & $\begin{array}{c}0.000 \\
*\end{array}$ \\
\hline $\begin{array}{l}\text { I shape good moral and take care of } \\
\text { other people. }\end{array}$ & 3.89 & 39.243 & $\begin{array}{c}0.000 \\
*\end{array}$ \\
\hline
\end{tabular}

\section{REGRESSION}

$X$ is defined as LOHAS. $Y$ is defined as consumption behavior.

According to the following Table IV, I observed that the equation is available because of $\mathrm{R}=0.775$, $\mathrm{R}$ Square $=0.601$, and Adjusted R Square $=0.553$.

According to Table V, dependent variable is consumption behavior and predictors is LOHAS. Lifestyles of health and sustainability have an influence on consumption of eco bags because of sig. $=0.000$.

According to Table VI, dependent variable is consumption behavior. There is a linear relationship because of sig. $=0.000$.

$$
y=a x+b
$$

$$
y=0.279 x+3.530
$$

This result indicates that equation is meaning. The increasing of one more LOHAS customers will lead to an increase of the co-efficient of consumption of each eco bag by 0.279 .

According to data from Government of Macao Special Administrative Region Statistics and Census Service, the population of Macao is 557400 in December 2011. The result of prediction is 155518 .

\begin{tabular}{|c|c|c|c|c|}
\hline Model & $\mathrm{R}$ & R Square & Adjusted R Square & $\begin{array}{c}\text { Std.Error of the } \\
\text { Estimate }\end{array}$ \\
\hline 1 & 0.775 & 0.601 & 0.553 & 1.461 \\
\hline
\end{tabular}

\begin{tabular}{|c|c|c|c|c|c|c|}
\hline \multicolumn{2}{|c|}{ Model } & $\begin{array}{c}\text { Sum of } \\
\text { Squares }\end{array}$ & df & $\begin{array}{c}\text { Mean } \\
\text { Square }\end{array}$ & F & Sig. \\
\hline 1 & Regression & 398.752 & 1 & 398.752 & 186.694 & 0.000 \\
\hline & Residual & 476.297 & 223 & 2.136 & & \\
\hline & Total & 875.049 & 224 & & & \\
\hline
\end{tabular}

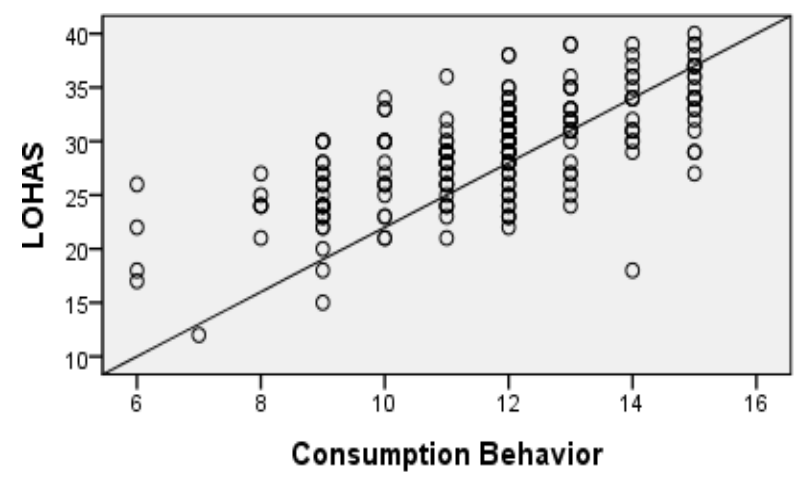

Fig. 5. LOHAS and consumption behavior

TABLE VI: COEFFICIENTS

\begin{tabular}{|c|c|c|c|c|c|}
\hline Model & & $\begin{array}{c}\text { Unstandardized } \\
\text { Coefficients }\end{array}$ & $\begin{array}{c}\text { Standardized } \\
\text { Coefficients }\end{array}$ & & \\
\hline 1 & $\mathrm{~B}$ & Std. Error & Beta & $\mathrm{t}$ & Sig. \\
\hline Constant & 3.530 & 0.606 & & 5.826 & 0.000 \\
\hline LOHAS & 0.279 & 0.020 & 0.675 & 13.664 & 0.000 \\
\hline
\end{tabular}

\section{CONCLUSION}

Consumers who feel satisfied with current society and hold optimistic attitude for future and consumers who usually use environment-friendly products have different choices on vision. The vision of eco bags is designed with different styles to attract their eyes.

Consumers who often take exercises and enjoy leisure activities, and Consumers who shape good moral and take care of other people have different choices on pattern. So difference of pattern designs should be considered in design step of eco bags.

LOHAS consumers have diversity of choices on sizes of eco bags, exclusion of consumers who shape good moral and take care of other people. In order to meet consumers' demands, company should design different types of sizes.

LOHAS consumers have all kinds of preferences for shapes of eco bags, except consumers who are keen on 
natural environment along with worry about pollution of natural environment. Various Shapes of eco bags should be designed to meet different consumer groups of LOHAS.

Consumers who favor eco bags have significant differences shown in the purchase of bags. According to different groups of LOHAS, if eco bags attract more consumers' effort to achieve an environment-friendly society, all kinds of eco bags should be designed to meet demands of different LOHAS consumers. The higher Means is that I often take exercises and enjoy leisure activities. That is to say, those consumers strongly prefer consumption of eco bags a top priority. Next, Consumers who are concerned about own health and family health prefer consumption of eco bags bigger than other clients.

According to the result of model, LOHAS impacts their consumption behavior of eco bags. Provided that LOHAS is widely promoted in citizens' life of Macao, the number of consumers who buy eco bags will increase.

\section{REFERENCES}

[1] Y. H. Ho, "A study on the LOHAS concepts, lifestyle, green consumption behavior, and sustainable living behavior," Master Thesis, pp. 2, Management Dept., Da-yeh University, Changhua, Taiwan, China, 2012.
[2] S. Y. Chen, "A study of the degree of LOHAS and cognition, attitude and behavior of green consumption for university students in Tainan city," Master Thesis, pp. 3, Eco-tourism Dept., National University of Tainan, Tainan, Taiwan, China, 2009.

[3] X. Y. Chen, "A research on green designing and art deco style applied to shopping bag," Master Thesis, pp. 2\&140, Dept. of Creative Design., Ming Chuan University, Taipei, Taiwan, China, 2010.

[4] S. C. Liang, "A study LOHAS concept in daily used products designing," Master Thesis, pp. 21, Dept. of industrial Design, Tatung University, Taipei, Taiwan, China, 2008.

[5] Y. J. Chen, "A study of the tendency about green consumption towards the recognition of food green marketing and the patterns of LOHAS," Master Thesis, pp. 150, Dept. of Food Industrial Management., Tunghai University, Taizhong, Taiwan, China, 2011.

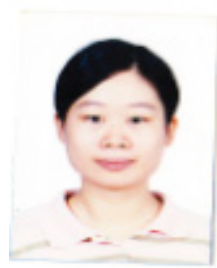

Qing Li was born on 21 September 1982. She comes from Nanning, Guangxi, China. She learnt business administration from September 2003 to July 2007 and obtained bachelor of management in faculty of management, Guizhou University, Guiyang, Guizhou, China. She learnt business administration from September 2009 to July 2011 and obtained master degree in faculty of management, City University of Macau, Macau, China. She is studying business administration for doctor degree in faculty of management, City University of Macau, Macau, China.

Now, she is interested in research on environmental protection, consumers, and business. 